\title{
1 WhAT DO PEOPLE GET OUT OF NEIGHBOURHOOD INITIATIVES ... OR NOT?
}

This chapter juxtaposes the intentions of local initiatives and their actual effect on interethnic encounters. Participation in initiatives has different meanings to different people, not to mention different ethnic and socioeconomic groups. Participation, of course, also has a different meaning for key actors than for "ordinary" participants. Participation occurs at different stages in the development cycle of initiatives, thus it is never static but rather a process of meaningful dialogue and consensus building between participants and different stakeholders. Most participants ask themselves key questions before participating:

What advantage might participation bring me?

How will the initiative help me build relationships?

Am I expanding my opportunities?

Though the real effects of interethnic encounters are not strictly predictable, the process of local engagement and participation is an essential component of interethnic exchange and individual and community development at the neighbourhood level. It empowers participants by facilitating the sharing of ideas and encourages active involvement through the participation of residents in decision-making processes. This is often a new experience for many participants. These local initiatives seek to remove barriers that limit the participation of marginalised citizens and strengthen their autonomy, also in other spheres of their life. Thus, participation builds local strength, creativity and resourcefulness and actively seeks to decrease vulnerability.

\subsection{Initiatives' aims and intentions versus real effects}

The initiatives described in this handbook are mostly small-scale projects. They were begun and financed by many different organisations, including municipalities, housing associations, welfare organisations, and the residents themselves. In Vienna, it is more common to have top-down projects, financed and implemented by the City of Vienna, while in Amsterdam official institutions usually collaborate with 
active residents, resulting in hybrid arrangements. This is the case for the initiatives discussed here, but is even more true when looking at the full body of initiatives in the case study neighbourhoods. Each city was selected deliberately to include different types of initiatives.

In Amsterdam, projects intend to encourage residents to take responsibility for their neighbourhood. They often aim to improve liveability by activating residents and bringing them into contact with one another. However, the added value of many of the analysed initiatives does not lie solely in the creation of new social contacts, but also in the low-threshold services that are offered (for example, helping residents fill out forms or bringing them into contact with social services). The Amsterdam initiatives generally strive to create a cosy atmosphere, where residents can feel 'at home'. Although participants appreciate this, these types of projects also tend towards (ethnic) sameness. This means that other residents can feel excluded, and in some cases this even resulted in conflicts between different resident groups. It is therefore not surprising that the initiatives and activities which generated the most - positively experienced - interethnic contact were the ones actively moderated by active residents or social workers.

In the Viennese context, a difference was found between top-down and bottomup initiatives. A strength of the analysed top-down projects is that they offer lowthreshold opportunities for residents to come into contact with institutions, such as educational organisations or housing associations. On the other hand, the more structured form of these initiatives offers fewer opportunities for (interethnic) contact with other participants. This form of contact is easier to establish in bottom-up initiatives, however here too contacts are generally between residents of the same ethnic group, or between participants who are similar in terms of, for example, social class or lifestyle. Activities where participants establish and maintain public or common areas - like shared urban gardens - do not necessarily result in contact with other participants, but they do lead to short interactions and encounters with residents and passers-by in public space.

In selected measures in Stockholm, two are top-down (open preschool and the Girl's Forum) and the rest are rather hybrid/bottom-up, that is, they depend directly or indirectly on funding from local administrations or external funds. However, they all rely on active citizens. The only initiative that can be characterised as a proper bottomup initiative is Swedish mekteb. The aims vary from initiative to initiative; empowerment and strengthening self-esteem (Girls Forum); strengthening links between active citizens to facilitate cooperation (Future Committee); a social venue with language cafes and cultural exhibitions (Folkets Hus Community Centre); a place to meet other parents on a daily basis (open preschool); young adults planning winter and summer festivals for children (Mitt127); and encouraging a Muslim identity in a Swedish context through learning and scouting (Swedish Mekteb). 


\subsubsection{Amsterdam: Disconnect between official aims and individual experiences}

Many of the selected initiatives in Amsterdam had ambitious aims, including objectives such as increasing social contacts (to combat loneliness and stimulate networking) and enhancing personal skills and self-development (including support to improve Dutch, reading and writing skills, financial know-how, ICT skills, selfconfidence). Apart from personal benefits, resident participation is thought to benefit the neighbourhood through, for example, reducing unemployment, improving behaviour in public space, increasing a resident's sense of security, and strengthening their attachment to the neighbourhood and fellow residents.

Participants do not always find it easy to express the ways in which the selected initiatives have improved their lives and/or their neighbourhood. While most enjoy their participation, there is a disconnection between the official aims of many initiatives and the benefits as experienced by participants. For example, in the case of initiatives that seek to reduce unemployment, the added-value for participants in practice turns out to be more social contacts and increased self-confidence, rather than finding a job or voluntary work.

Residents (both participants and non-participants) are sceptical of the current neighbourhood policy in Amsterdam and the Netherlands, which emphasises the role of residents in improving the neighbourhood. Generally, the interviewed residents agree that participation is positive, however, they also point out that there are often constraints on people's ability to participate because of other obligations such as work, school, or informal care, as well as barriers to participation, such as a lack of language skills or poor health.

Participation is experienced as a zero-sum game: Many of the participants we spoke to are active in neighbourhood initiatives because their personal circumstances allow for it. They are often retired, unemployed, or work part-time, and many state that they have become more or less active as a result of changes in their personal circumstances. Participants stress that participation of the type that is envisioned in current policies is time-intensive, and requires effort and skills, and is often unfeasible without extensive and ongoing support from institutions.

Apart from these more general observations, the case study initiatives differ in the degree to which they are able to realise their stated aims. They also generate different types and degrees of interethnic encounter. The main findings for each initiative are briefly discussed (see also Table 1). 
Table 1: Effects of initiatives in Amsterdam neighbourhood case studies

\begin{tabular}{|l|l|l|}
\hline \multicolumn{1}{|c|}{ Initiative } & $\begin{array}{c}\text { Do outcomes match stated } \\
\text { aims and intentions? }\end{array}$ & $\begin{array}{c}\text { Do they create } \\
\text { interethnic } \\
\text { encounters? }\end{array}$ \\
\hline Vrouwenbazaar & No & No \\
\hline Pek-o-Bello & No & Partially \\
\hline VoorUit & Yes & Yes \\
\hline Dobbekamer & Yes & Yes \\
\hline Tante Ali & Partially & Partially \\
\hline Buurthuiskamer Eigen Haard & Partially & Partially \\
\hline Buurtambassadeurs & Partially & Yes \\
\hline De Handreiking & Partially & Yes \\
\hline
\end{tabular}

Vrouwenbazaar (Van der Pekbuurt, bottom-up) aims to empower migrant women, promote intercultural understanding and contribute to social contacts in the neighbourhood. Activities are mostly attended by migrant women from majority Arabicspeaking countries, most of whom do not live in the neighbourhood. Thus, the initiative has trouble attracting a diverse range of participants. Some residents actively dislike the organisation as its meeting place used to belong to another neighbourhood centre (mostly frequented by long-term native Dutch residents) which had to close down. Due to financial difficulties, the Vrouwenbazaar lost their meeting space which was converted into a more general neighbourhood centre (where they still organise activities).

Pek-o-Bello (Van der Pekbuurt, bottom-up) calls itself a neighbourhood enterprise or 'trust' that aims to have residents perform tasks that are currently performed by the district administration, such as the maintenance of public space. Like the Vrouwenbazaar, Pek-o-Bello is controversial in the neighbourhood because it is believed to compete with other neighbourhoods organisations for subsidies. In addition, some residents do not think that the initiators are representative of the neighbourhood. While Pek-o-Bello makes the effort to reach out to residents, at the time of research they had not yet organised many activities and had trouble attracting a diverse group of participants (especially participants with a migration background and/or non-middle class participants).

Dobbekamer, Tante Ali, and Eigen Haard buurthuiskamer (Slotermeer-Noordoost, hybrid) are three neighbourhood centres that are similar in design. All three offer a place for residents to socialise and organise activities. While participants belong to different ethnic groups, within activities there is more ethnic homogeneity. In fact, some participants indicate that they feel excluded because of their ethnic background. In all three centres, activities that are most successful are coordinated by very active 
volunteers or housing association employees who attempt to make everybody feel welcome. However, these very active volunteers also indicate that this takes up a lot of time and energy, and some report feeling overburdened.

VoorUit (Slotermeer-Noordoost, top-down) is a project initiated by the VU University in a number of highly ethnically diverse Amsterdam neighbourhoods. Students are provided with rent-free housing in exchange for performing voluntary work in their neighbourhood. In Slotermeer-Noordoost both activities for children and language classes for adults are organised. The students are successful in reaching out to residents, and they are generally liked and trusted in the neighbourhood. The initiative's top-down structure and the incentive for students in terms of rent-free housing makes the organisation relatively professional. However, this also means that residents are mostly involved as rather 'passive' participants who attend activities, rather than organising these themselves.

Buurtambassadeurs (H-buurt, hybrid) is an initiative that aims to bridge the 'gap' between residents and the district administration by appointing neighbourhood ambassadors (two residents per neighbourhood) who can act as intermediaries. The initiative allows the ambassadors to build more extensive and diverse networks, but it is also demanding of their time and energy as ambassadors are expected to represent the neighbourhood and advocate for the neighbourhood residents on the one hand, and on the other hand to communicate and uphold 'common norms' and liveability standards which are determined by the district administration and housing associations. Both H-buurt ambassadors report feeling overwhelmed by the demands of their voluntary work.

De Handreiking (H-buurt, hybrid) is a neighbourhood centre that intends to activate vulnerable residents with the aim of finding employment or voluntary work. The initiative draws an ethnically diverse range of participants who appreciate the activities offered (mostly Dutch language classes, hairdressing and various crafts). Activities are ethnically mixed, even if participants do not always have interethnic contacts but rather socialise 'side-by-side'. However, the intended methodology of having residents themselves design activities and learn from each other has as yet not really been implemented, as the centre is very dependent on the efforts of (paid) social workers. In addition, the aim of improving participants' chances on the labour market is rather ambitious. 


\subsubsection{Vienna: Targeted to specific social groups with unexpected positive side effects}

Initiatives in Vienna tend to cater to specific social or ethnic groups and thus a strong interethnic mix of participants is mostly not achieved. Next to interethnic encounters, some initiatives also produced unexpected positive side effects. Participant motivations and expectations differ between the initiatives. Some examples will be given in Table 2 below.

Table 2: Effects of initiatives in Viennese neighbourhood case studies

\begin{tabular}{|l|l|l|}
\hline \multicolumn{1}{|c|}{ Initiative } & \multicolumn{1}{|c|}{$\begin{array}{c}\text { Do outcomes match } \\
\text { stated } \\
\text { aims and intentions? }\end{array}$} & \multicolumn{1}{|c|}{$\begin{array}{c}\text { Do they create } \\
\text { interethnic } \\
\text { encounters? }\end{array}$} \\
\hline Free pre-school & Partially & Partially \\
\hline Neighbourhood Centre & Partially & No \\
\hline Gardening around the Corner & Yes & No \\
\hline Matzner Garden & Partially & No \\
\hline Learning Together & Yes & Partially \\
\hline Community Center Herbststraße 15 & Yes & Partially \\
\hline
\end{tabular}

Free pre-school (top-down, citywide) is provided by the City of Vienna and available to all Viennese children regardless of nationality. The initiative aims to integrate children from all social groups and to allow parents to combine family and work commitments. The interviews, however, show that many parents still choose a private kindergarten for their children. Especially the requirement of both parents' employment ${ }^{2}$ is difficult to fulfil for migrant women (when work requires childcare and vice versa). In addition, both Austrian and non-Austrian ${ }^{3}$ interviewees believed the private kindergarten to be better for children's German language skills, something attributed to the better carer-child-ratio.

The Neighbourhood Centre (top-down, citywide), provided by the Hilfswerk, is a low threshold meeting point in the neighbourhood. All residents are welcome, however in practice mainly specific social groups attend, usually pensioners and people in difficult (psychological) life situations. These participants, who are mostly Austrian, use the donation-based classes to structure their days as well as to be active and meet

\footnotetext{
$2 \quad$ This refers to the time before the obligatory years of pre-school (two years before enrollment in elementary school).

${ }^{3}$ The terms 'Austrian' and 'non-Austrian' do not refer to citizenship, but to migration background.
} 
other participants. The findings also show that the regularity of the activities provides a basis for more in-depth contacts. However, there is no evidence that this form of social bonding results in a higher degree of neighbourhood belonging. This might be because participants come from a larger catchment area.

Gardening around the Corner (hybrid, citywide), provided by the district government and the urban renewal offices, was developed primarily to improve the urban environment through the legalisation of former ad-hoc 'guerrilla gardening' activities. Residents take care of designated small green plots on the street because they want to make their neighbourhood a nicer place by contributing to urban greenery and/or because they lack a privately-owned garden. This voluntary activity - which is mostly carried out by Austrian middle-class residents - triggers communication in public space - with neighbours as well as with strangers. While this is not the initiative's primary intention, new contacts and supportive practices (e.g. watering or donation of plants) have emerged as a positive side effect.

The goal of Matzner Garden ${ }^{4}$ (bottom-up, $14^{\text {th }}$ district), organised by local residents, is to provide a space for urban gardening and activities in the neighbourhood, in order to promote contacts among local residents and strengthen their belonging. Primarily Austrian, middle-class residents are engaged in this initiative. The interviews show that people from migrant groups often did not feel addressed by or included in the initiative, even though they were explicitly invited to participate.

Learning Together (bottom-up, $16^{\text {th }}$ district), an association funded by public and private sponsors, provides resources, training and information for immigrant women, children and families to promote their integration. While the initiative aims to achieve equal opportunities for immigrant families in general, there is a specific focus on the Turkish community. Participants seek to improve their German language skills, but also use the service for counselling and advice. Since the teachers are usually Austrians with Turkish language skills, the initiative has a good effect on 'vertical relations', that is, connections of individuals to institutions. The initiative has an empowering effect on the participants.

The community centre Herbststraße 15 (top-down \& bottom-up, $16^{\text {th }}$ district), provided by the Urban Renewal Office 16, Caritas and the district government, aims to bring people together in the neighbourhood. The centre offers a teaching and learning space, a space for activities such as sewing or cooking as well as advice and language lessons. In the sewing course, for example, women of different ethnic backgrounds (mainly Muslim women) get together. The initiative offers them a space to meet other women outside of their home, talk, make friends, but also to learn something new whether they speak German or not. The initiative has an empowering effect since participants learn about available (free) services in the district and city.

www.matznergarten.at 


\subsubsection{Stockholm: Need for further support structure to go from operational to sustained strategic impact}

None of the initiatives (see Table 3) have interethnic coexistence stated as an objective. Rather ethnic mix is an outcome of coincidence (a success of the initiative), or by the local neighbourhood's demography. Participants express several aspects of contentment from participating, such as learning new things, meeting people or simply getting out of the house. Had they not been pleased, they would not have come. Any dissatisfaction expressed related to a lack time, support or interest from local authorities.

Table 3: Effects of initiatives in Stockholm neighbourhood case studies

\begin{tabular}{|l|l|l|}
\hline \multicolumn{1}{|c}{ Initiative } & \multicolumn{1}{c|}{$\begin{array}{c}\text { Do outcomes match } \\
\text { stated } \\
\text { aims and intentions? }\end{array}$} & \multicolumn{1}{c|}{$\begin{array}{c}\text { Do they create } \\
\text { interethnic encounters? }\end{array}$} \\
\hline Swedish Mekteb & Yes & Yes \\
\hline My 127 & Yes & Yes \\
\hline Open Pre-school & Yes & Yes \\
\hline $\begin{array}{l}\text { Folkets Hus } \\
\text { Community centre }\end{array}$ & Partially & Partially \\
\hline Future Committee & No & Yes \\
\hline Girls Forum & Yes & Yes \\
\hline
\end{tabular}

Swedish Mekteb (Group-based, bottom-up, Skärholmen)

The organisation is funded by membership fees and the sobriety movement IOGTNTO. Swedish Mekteb aims to retain Muslim identity while supporting integration into Swedish society. They organise activities for their members that can be seen as typically Swedish. The members can explore the Swedish culture together with fellow Muslims. The initiative enhances the possibility of integration in the community, although continuation of the organisation depends on engaged members.

\section{My 127 (Place-based, hybrid/top-down, Skärholmen)}

"For youths by youths". The festival is funded by the city administration and sponsors. The concept is based on the fact that young people in the area are responsible for planning and conducting the festival during a few weeks in summer and winter. This can be done by employing more young people who work in the summer. The project has clear advantages that older youths are responsible and act as role models for other young people. The festival has spread across the region and the country. 
Open Pre-school (Group- \& placed-based, top-down, Rågsved)

Open pre-school is a publicly funded meeting place for parents and their children as well for childminders during their work hours. There are no rules for registration and no fees and is often seen as a complementary concept for the regular childcare, when there is a pre-school-like environment where at-home parents and their children can meet each other and engage in activities led by professionals with materials and toys provided at the location. Open pre-school is a well-established concept in Swedish society. This allows different nationalities and cultures to meet on common ground. The dedicated staff and participants create opportunities for knowledge sharing and integration that might not occur naturally.

\section{Community centre Folkets hus (Placed based, hybrid, Rågsved)}

Folkets Hus, which is a nationwide organisation, aims to create opportunities for democracy, social development, cultural activities, entertainment, education and creative expression by providing attractive venues and activities for local community citizens where citizen participation and involvement is encouraged. Organisations, clubs or individuals can use the facilities for a fee. In Rågsved, many activities come together in the facility, located in the central public square. Folkets Hus in Rågsved houses a café run by their own staff and they have both smaller and larger rooms for rent. Organisations and activities currently popular at the location include: a language café, movie nights, dance nights and book clubs. People not engaged in the group activities can also use the facilities by visiting the café or sitting in the public area. Folkets Hus has an impact on interaction between persons with different backgrounds and interests, who possibly wouldn't meet on an everyday basis.

\section{Future Committee (Placed-based, hybrid/bottom-up, Rinkeby)}

Rinkeby Future Committee is a network of local groups, associations and organisations, with interests in the neighbourhood. The group aims to strengthen collaboration and cooperation between local stakeholders in order to improve the area of Rinkeby by working together as a team. The strength of the cooperation is the overall will to improve the area, anyhow some tensions have arisen due to vested interests that in some cases can counteract efforts within the initiative.

\section{Girl's Forum (Placed- \& group-based, top-down, Rinkeby)}

Girl's Forum was founded by the organisation Save the Children and the Urban District administration. The initiative enables young women to visit, the otherwise maledominated youth centre. Girl's Forum organises girl's evenings for young women. The activities vary, but are focused on strengthening the girls' knowledge and skills in terms of their rights and opportunities. 


\section{Reflections from Practitioners in Urban and Regional Planning in Stockholm:}

The variation of top-down, bottom-up and hybrid initiatives is something that permeates each project and can also be observed in reality. Planning theory requires a complex network of participating actors, both public, private and individual, something which has been proven in the research of ICEC. A side-effect of the observations in the neighbourhoods is a degree of project fatigue among both residents and public officials, and a favouring of interaction and networking in order to address specific problems or to simply make things happen.

\section{SUMMARY:}

\section{Variety of Initiatives At Neighbourhood Level With a Focus on Small-Scale Projects}

The initiatives described in this handbook are mostly small-scale projects. They are initiated and financed by many different organisations, including municipalities, housing associations, welfare organisations, and by residents themselves. In Vienna, it is more common to have top-down projects, financed and implemented by the city of Vienna, while in Amsterdam official institutions usually collaborate with active residents, resulting in hybrid arrangements. This is the case for the initiatives discussed here, but it is even more true when looking at all of the initiatives in the case study neighbourhoods. The selection of each city deliberately included different types of initiatives.

\section{ZUSAMMENFASSUNG:}

Die in diesem Handbuch beschriebenen Initiativen sind meist räumlich begrenzt und bewegen sich hinsichtlich ihrer finanziellen Ausstattung in einem limitierten Rahmen. Initiiert und finanziert werden sie von unterschiedlichen Organisationen, wie der Stadtverwaltung, Wohnbaugesellschaften, aber auch aktiven BürgerInnen. In Wien dominieren nach wie vor die Top-down-Projekte der Stadt Wien, in Amsterdam finden sich eher hybride Initiativen, die auf einer engen Kooperation zwischen Stadtverwaltung und aktiven BewohnerInnen basieren. Die Auswahl in dieser Forschungsstudie wurde dahingehend getroffen, jeweils unterschiedliche Typen von Projekten zu berücksichtigen. Die Amsterdamer Initiativen haben gemeinsam, dass sie die BewohnerInnen motivieren wollen, selbst Verantwortung für ihr Wohnumfeld zu übernehmen und weisen eher hybride Strukturen auf. Ihr Mehrwert liegt nicht nur in der Anbahnung interethnischer Sozialkontakte, sondern auch in niederschwelligen Serviceangeboten. In Wien sollen eher bestimmte soziale Gruppen angesprochen werden und die interethnische Vielfalt 
der TeilnehmerInnen ist explizit angestrebt. Das Gesagte gilt für die hier analysierten Aktivitäten, aber noch mehr für die Gesamtheit der in den jeweiligen Stadtvierteln vorhandenen Initiativen.

\section{SAMENVATTING:}

De initiatieven die worden besproken in dit handboek zijn over het algemeen kleinschalig: ze richten zich op de bewoners van één buurt of meerdere dicht bij elkaar gelegen buurten. Binnen de geselectereerde initiatieven bestaat er een grote variatie aan organisatie- en financieringsvormen. Zowel de gemeente, woningbouwverenigingen, maatschappelijke organisaties als bewoners zelf kunnen initiefnemer zijn. In Wenen zien we met name zogeheten, top-down' projecten, die worden bedacht, gë̈mplementeerd en gefinancierd door de gemeente. In Amsterdam daarentegen vinden we vooral , hybride" initiatieven, waarbij officiële instanties samenwerken met vrijwilligers (vaak buurtbewoners). Hun activiteiten zijn erop gericht om bewoners te motiveren zich meer met de buurt bezig te houden en verantwoordelijkheid te nemen voor hun woonomgeving, bijvoorbeeld door het schoonhouden van hun eigen straat of het aangaan van contacten met eenzame buurtbewoners. Dankzij deze samenwerking tussen actieve bewoners en (medewerkers van) officiële instanties ligt de toegevoegde waarde van dit soort initiatieven niet alleen in het feitelijke doel dat wordt bereikt (bijvoorbeeld een schone straat) maar ook in het creëren van laagdrempelige contacten met hulpverlening of andere diensten. In Wenen hebben initiatieven vaak tot doel bepaalde gemarginaliseerde sociale groepen te bereiken. Interetnische diversiteit van de deelnemers is vaak een expliciet streven. Bovenstaande geldt voor de door ons onderzochte initiatieven, maar des te meer voor het totaal van aanwezige initiatieven in een buurt of stadsdeel. Met het oog op het bereiken van variatie hebben we in beide steden namelijk bewust allerlei verschillende soorten projecten opgenomen. 